\title{
Accounting Standards for Semi-Autonomous Agencies: Experiences and Lessons from Indonesia
}

\author{
BUDI WALUYO* \\ Polytechnic of State Finance STAN
}

\begin{abstract}
The adoption of accrual accounting in government agencies has been so widespread. Following the global trend, the Indonesian administration has implemented governmental accounting standards for its agencies. This study aims to explain accounting standards in the context of agencification, i.e., the use of semiautonomous agencies to deliver public services. The paper explores the formulation and implementation of accounting standards by investigating cases from semi-autonomous agencies in Indonesia. The data were collected through semi-structured interviews with agency officials, policymakers, standards-setters, and experts. The results were analyzed through an inductive-deductive approach. The study shows that while accrual accounting has stimulated fundamental change in agencies' financial reporting, dual accounting standards are considered unnecessary by agency managers, policymakers, and standard-setters. The research also reveals constraints in developing accounting systems in the agencies.
\end{abstract}

Keywords: Accounting Standards, Accrual Accounting; Agencification; Government Accounting; Semi-Autonomous Agencies

Abstrak: Penerapan akuntansi akrual di instansi pemerintah semakin meluas. Mengikuti tren global, pemerintah Indonesia menerapkan standar akuntansi pemerintahan untuk instansi pemerintah. Penelitian ini bertujuan menjelaskan standar akuntansi dalam konteks agensifikasi, yaitu penggunaan badan semi-otonom untuk menyediakan layanan umum (Badan Layanan Umum, BLU). Artikel ini membahas perumusan dan penerapan standar akuntansi dengan studi kasus pada BLU di Indonesia. Data diperoleh melalui wawancara semi-terstruktur dengan pejabat BLU, pembuat kebijakan, penyusun standar, dan pakar. Hasil wawancara dianalisis dengan pendekatan induktif-deduktif. Hasil penelitian menunjukkan bahwa di satu sisi akuntansi akrual telah mendorong perubahan mendasar pada pelaporan keuangan $B L U$, namun di sisi lain dua standar akuntansi dianggap tidak perlu oleh pengelola BLU, pembuat kebijakan, dan penyusun standar. Penelitian ini juga menemukan kendala dalam pengembangan sistem akuntansi di BLU.

Kata Kunci: Standar Akuntansi, Akuntansi Akrual, Agensifikasi, Akuntansi Pemerintahan, Badan Layanan Umum

\footnotetext{
* Corresponding author: budiwaluyo@pknstan.ac.id
} 


\section{Introduction}

The implementation of public sector management reform has been inspired by the notions of competition, decentralized authority, and increased flexibility (Osborne and Gaebler, 1992) to improve the efficiency and economy and protect the consumers and citizens (Christensen et al., 2008). This reform has also experienced a shift in the balance between bureaucratic autonomy and bureaucratic integration, marked by 'agencification' (Thynne, 2003), which refers to a delegation of government tasks to semi-autonomous agencies (Flinders and Smith, 1999; Pollit et al., 2004).

Agencification has taken place in Indonesia since 2005 by introducing semiautonomous agencies (hereafter: 'agencies') at an arm's length distance from bureaucracy; this is called Badan Layanan Umum (BLU, in English: Public Service Agencies). Concerning accounting, at the beginning of the adoption, these agencies have to comply with two accounting standards: The Government Accounting Standards (Standard Akuntansi Pemerintahan, SAP) and Financial Accounting Standards (Standard Akuntansi Keuangan, SAK). Consequently, from 2005 to 2015, they had to prepare two different financial statements following each standard. In 2015, the government enacted a new statement of SAP, which combined principles from both standards and terminated dual reporting requirements. Details of this reform will be given below.

The developments of agencification have been accompanied by a plethora of literature applying theoretical and empirical research. So far, scholars mostly have put much attention on administrative history, reform, and change (e.g., Pollitt et al., 2004) and what effects agencification might cause on actual political-administrative behavior, organization structures, procedures, and legal capacities (Egeberg and Trondal, 2009; Yesilkagit and van Thiel, 2008). However, little has been done to explore the accounting aspects of the agencies. Agencification has scarcely been researched from an accounting perspective. Hence, this study investigates how accounting standards are implemented in the context of agencification by examining whether the standards have been properly designed to meet agencies' characteristics. 
Given that accrual accounting and agencification are mainly implemented in Western countries, observing this adoption in developing countries is essential to understand how this concept works in different politico-administrative settings (OECD, 2002). Therefore, this research explores cases in Indonesia, as a developing country where the adoption of accrual accounting and agencification is a relatively new phenomenon. In Indonesia, agencification has been chiefly introduced in public service agencies, including state universities and hospitals. These agencies are diverse in size, core task, and main ministry. Thus, there may be considerable variability in accounting practices. A similar model and purpose may result in different outcomes depending on the circumstances in which it is applied (Siallagan and Stewart, 2014).

This study focuses on examining the adoption of accrual accounting in supporting agencification by exploring the experience of Indonesia. Drawing on the ideas from New Public Management, this study addresses two questions: (1) how accounting standards formulated in the context of agencification was? Moreover, (2) how was accrual accounting implemented in semi-autonomous agencies? The study unveils how accrual accounting has stimulated changes in financial reporting. Agency managers, policymakers, and standard-setters consider dual accounting standards as unnecessary at the beginning of the adoption. This study also reveals three lessons learned, including difficulties in developing accounting systems in the observed agencies.

The remainder of the article is organized as follows. The following section provides an overview of semi-autonomous agencies and a review of government accounting standards to introduce the theoretical framework adopted in this study. Later on, the design of the study is outlined. The following sections describe the dynamics of accounting standards in the agencies. The final section provides a discussion in the light of the theory and concluding remarks.

\section{Theoretical Framework}

\subsection{Semi-autonomous Agencies}

Agencification is defined as the delegation of tasks to structurally disaggregated public agencies (Van Thiel, 2001; Verhoest et al., 2012) or the transfer of government 
activities into agency-type organizations (Pollitt et al., 2001; Pollitt and Talbot, 2004). They can be recentralized, merged, or abolished. Therefore, the loss of control is less than in the case of privatization (James et al., 2015).

Semi-autonomous agencies provide public services proposed by government actors (James, 2000) and have a certain degree of autonomy from their respective ministry in policy, decision making as well as over personnel, financial, and managerial matters (Christensen et al., 2008), and organization structure (Overman and van Thiel, 2016). Another label for agencies is quasi-autonomous non-governmental organizations quangos (Greve et al., 1999; Pliatzky, 1992; Van Thiel, 2001, 2004). They are not corporate bodies with primarily commercial purposes; they are not statutorily independent bodies that are free from ministerial control; and they are not third sector bodies voluntarily created to achieve the goals of their members (Pollitt et al., 2004: 89).

The number and importance of these agencies have been growing over the past decades (Flinders, 2004) and increased significantly in almost all countries around the globe (Pollit et al., 2001; Van Thiel, 2001, 2004; Verhoest et al., 2010). Following the wave of gentrification in western countries and supranational organization such as the European Union (see, e.g., Howell, 2019; Maggetti et al., 2019), this trend is adopted in the eastern and developing countries such as Papua New Guinea (Ugyel et al., 2020), Nigeria (Aliu and Ibikunle, 2020), and Indonesia (Restianto and Bawono, 2020; Waluyo, 2018). While the growing trend towards the rationalization and consolidation of the agency landscape (Szesciło, 2020) and post-agencification issues (see, e.g., Migliorati, 2020), many have claimed that the idea of agencification would trigger the agencies to be more professional, their management would be more business-like, and they would offer higher quality services compared to government bureaucracy (Osborne and Gaebler, 1992; Pollit et al., 2001). Apart from better output quality, agencies are expected to be more efficient public service providers (e.g., Bach, 2012; Pollitt et al., 2001) in achieving value-for-money in public spending (Cingolani and Fazekas, 2020). However, a recent study found a negative effect of agencification on both public sector output and efficiency (Overman and van Thiel, 2016). 
Agencification has signified a transfer of government activities to agency-type organizations vertically specialized outside ministerial departments (Egeberg and Trondal, 2009). It became widely recognized that an increase in cost-efficiency was inevitable, and hence modern business management techniques such as accrual accounting had to be introduced. The civil service opened its doors and minds for a modern management technique (Kosar, 2011). In the meantime, a survey conducted in the Italian local government showed the importance of cash- and commitment-based accounting in the overall system was overwhelming. In contrast, the marginality of the 'new' accrual-based reporting was evident. In the opinions of preparers, accruals accounting was not seen as a useful tool, and the link with internal needs and managerial control systems were absent (Nasi and Steccolini, 2008).

Agencification has been high on the agenda of administrative policymakers, partly because of the New Public Management (NPM) wave. Two decades of the NPM reforms have made the agencification phenomenon highly topical and attracted considerable scholarly attention (Trondal, 2014). Despite policy conditionality has changed the domestic agencification pattern (Lampropoulou and Oikonomou, 2020), NPM practices play a role in developing responsiveness and goal-oriented characteristic of the agencies (Yee and Van Thiel, 2020). Hence, governments across continents have established agencies at arm's length from ministerial departments to deliver particular regulatory and administrative tasks (Pollitt et al., 2004; Verhoest et al., 2010).

In the Indonesian central government, semi-autonomous agencies, also called BLU, are operated under their main ministries and supervised by the Ministry of Finance (MoF). The main ministry is the main principle, while the MoF can be considered as the secondary principal. For example, Gelora Bung Karno is a BLU under the Ministry of State Secretariat, managing sports facilities. Lembaga Pengelola Dana Bergulir (LPDB, in English: Agency of Revolving Fund) is a BLU under the Cooperative and SmallMedium Enterprise Ministry. Meanwhile, BLU may operate under multiple parent authorities. For example, Lembaga Pengelola Dana Pendidikan (LPDP, in English: the Indonesian Endowment Fund for Education) is a BLU under the supervision of three ministries: Ministry of Finance, Ministry of Education, and Ministry of Religion. 
State hospitals and educational institutions mainly adopt BLU governance. Based on Law 44/2009 on Hospitals, state hospitals are mandated to adopt BLU status. BLU hospitals play a crucial role in health care services. Almost $70 \%$ of health expenses claims for insurance came from state hospitals, and the large hospitals among them had adopted BLU status (MoF, 2016). Central hospitals such as Rumah Sakit Cipto Mangunkusumo (general hospital) and Rumah Sakit Pusat Angkatan Darat (military hospital) are among the largest BLUs. In 2016, their revenue exceeded IDR 1 trillion (around GBP 50 million) per year, respectively (MoF, 2016).

Almost all the leading state universities have adopted BLU. In addition to independence and academic freedom, universities need flexible governance. The Law 12/2012 on Higher Education has mandated higher education institutions to adopt BLU before moving further into a more independent establishment as a state-owned legal entity.

Following the introduction of BLU in the ministries of the central government, the administration decided to extend the use of this governance at the local level. In 2007, the Ministry of Internal Affairs enacted Regulation 61/2007 on Local BLUs. In local government, they are called BLU Daerah (BLUD, in English: Local BLU). For example, Trans Semarang is a BLUD in Semarang City which serves public transportation within the city.

Local regulations on BLUD should refer to the regulation of BLU. Local authorities should develop local arrangements based on the concept of the central government. They have to refer to the national platform of BLU governance to develop BLUD arrangements at the local level. Reflecting isomorphism (DiMaggio and Powell, 1983, p.151), more and more similar organizations are established. BLUD becomes a popular choice and is massively adopted by community-based agencies such as health centers.

\subsection{Government Accounting Standards (GAS)}

The intention of the Indonesian government in reforming public sector accounting was initiated at the beginning of the 1980s. The initiative of donors and the spirit of democratization and decentralization became the significant drivers (Ika and Widagdo, 
2013). In the 2000s, the government considered introducing SAP in the traditional budgetary accounting system to enhance accountability and transparency in the reform process.

Starting government accounting reform, the MoF established Committee of Governmental Accounting Standards (Komite Standar Akuntansi Pemerintahan, KSAP) in 2002. Based on Law 17/2003 on State Finance, the government must implement the accrual accounting within five years since the law took effect in 2003. Therefore, the existence of this Committee had been legally strengthened since 2004 by Presidential Decree. KSAP replaces the Agency of State Finance Accounting (Badan Akuntansi Keuangan Negara) at the MoF.

The primary duty of KSAP is to set GAS as the principle for preparing financial statements. The Committee is divided into two divisions: Consultative Committee and Working Committee. Consultative Committee provides consultations and opinions in formulating the SAP concept, while Working Committee prepares, formulates, and drafts the SAP. Both of the committees report their activities to the Minister of Finance. KSAP consists of representatives from the MoF, the Ministry of Home Affairs, Finance and Development Supervisory Agency (Badan Pengawasan Keuangan dan Pembangunan), Indonesian Institute of Accountants, local government's representative, and higher education's representative.

In the process of standard formulation, arrangement, and development, the KSAP follows an international standard-setting due process which has been modified following the Indonesian regulation (Ika and Widagdo, 2013). In preparing an accounting standard, the KSAP refers to the general guidelines of accounting standards. The Committee takes a standardized process according to the guidelines. The Committee has a grand design for the development of SAP. Annually, they prepare priority topics to be developed as an accounting standard. Initially, KSAP assesses the considered topic. Afterward, a Working Committee is formed to do initial research by studying related regulations and problems.

The Committee appoints a working team for analyzing the issues, which will be prepared for standard setting. The team considers whether a topic should be released as 
an accounting standard or simply described in the so-called Buletin Teknis (in English: practical guidelines) because not all the issues can be formulated in the accounting standards.

KSAP adheres to the international accounting standards, best practices, and other standards in similar industries. In addition, the Committee also considers other references following the conditions and regulations in Indonesia. The SAP is not a translation of the international standards and not a full adoption of them. The international standards are preferred but are not fully adopted and translated due to the different conditions.

In the phase of the exposure draft, KSAP held a focus group discussion and limited hearing to get feedback. Meanwhile, the limited hearing included the BLU representatives to discuss the draft, resulting in the second exposure draft. The last was a public hearing by uploading the draft to the website and inviting all the stakeholders, academics, and society to discuss.

After the public hearing, KSAP requested an opinion from the Financial Audit Agency (Badan Pemeriksa Keuangan, BPK), as mandated by the law. The considerations were discussed in the plenary KSAP meeting. Lastly, they submitted the final SAP draft to the MoF to be legally released.

The formulation of the SAP in 2005 was part of more significant political and economic reforms following the financial and political crisis that occurred in 1998. Idealized in the early 1980s by technocrats in the MoF, accrual accounting practices were deferred and enabled by a series of national political events (Harun et al., 2012). This SAP employs a cash-towards-accrual (CTA) basis.

As mandated by the law, accrual accounting should be implemented by the year 2008. The KSAP began compiling accrual-based accounting standards. At that time, the government was not ready yet, and the standards had not been completed. Therefore, the administration consulted the parliament to defer the accrual-based accounting implementation. The parliament agreed on the extension for five years since 2009.

In 2010, KSAP released accrual-based SAP, which consisted of the Statement of Governmental Accounting Standards (Pernyataan Standar Akuntansi Pemerintahan, 
PSAP) number 1 to 12 . These PSAPs have been applied since 2015 for all government institutions. In 2015, all the government institutions started adopting accrual-based accounting. Several studies identified issues on this adoption include inadequate human resources capability, information technology, funds, and administration support (Kasim, 2015). At the end of 2015, the KSAP issued PSAP number 13 on 'Financial Reporting for Public Service Agencies', which had to be referred by BLU for preparing financial statements as of 2016 onwards.

\section{Research Method}

This study employs a case study approach to investigate a contemporary phenomenon with its real-life context (Yin, 2003) and examines the operation of causal mechanisms in individual cases in detail (George and Bennet, 2005). Accounting standards and practices in BLUs cannot be explored in a vacuum as it needs the context of agencification. At the beginning of the adoption, it is only in these agencies that dual accounting standards are developed and utilized. The case studies attempt to look for the limitations of the theoretical perspectives to address the gaps in the findings, which have not explored how accounting works in BLUs.

\subsection{Case Selection}

Table 1.

Overview of Selected Agencies

\begin{tabular}{lllc}
\hline Agency code & Tasks & Main ministry & Budget (2021)* \\
\hline SA & Education & Ministry of Health & 26 \\
\hline SB & Education & Ministry of Religion (MoR) & 186 \\
\hline SC & Education & $\begin{array}{l}\text { Ministry of Education, Culture, } \\
\text { Research, and Technology (MoE) }\end{array}$ & 371 \\
& & MoR & 514 \\
\hline LA & Education & MoE & 262 \\
\hline LB & Education & N/A (Independent) & 2,096 \\
\hline LC & $\begin{array}{l}\text { Area } \\
\text { management }\end{array}$ & MoE & 1,297 \\
\hline LD & Education & &
\end{tabular}

*in IDR billions, rounded

In order to address the issue of possible variability, this study examines the practice of accounting in seven agencies in Indonesia. The seven cases were carefully selected based on variation sampling (Given, 2008) to enable the exploration of how agencies 
with different sizes, tasks, and main ministries implement accounting standards (see Table 1).

\subsection{Data Collection and Analysis}

Data collection methods included interviews with key people at the agencies, mainly including the accounting or finance division head. The interview aimed to delve deep beneath the surface of superficial responses to obtain true meanings that key person assigns (Ribbens, 1989) to the accounting standards in the agencies. Semi-structured interviews were adopted, and all questions were open-ended to provide the interviewees with the flexibility necessary to express their personal experiences and perceptions towards the most critical issues (Boeije, 2010).

The interviewees were probed on their perceptions of accounting standards for BLUs, the current practice of accounting and financial reports, and the problems and challenges in implementing accounting principles. Table 2 shows an overview of the interviews employed for this study.

Table 2.

Overview of Interviews

\begin{tabular}{lll}
\hline $\begin{array}{l}\text { Agency code / } \\
\text { position }\end{array}$ & $\begin{array}{l}\text { Job Description/title } \\
\text { (number of people) }\end{array}$ & Respondent code \\
\hline SA & Supervisor of accounting & {$[\mathrm{SA} 1]$} \\
\hline SB & Supervisors of accounting (2) & {$[\mathrm{SB} 1],[\mathrm{SB} 2]$} \\
\hline SC & Accounting Manager & {$[\mathrm{SC}]$} \\
\hline LA & Head of Accounting Division & {$[\mathrm{LA} 1]$} \\
\hline LB & Head of Finance Division & {$[\mathrm{LB} 1]$} \\
\hline LC & Director of Accounting & {$[\mathrm{LC} 2]$} \\
\hline LD & Accounting Manager & {$[\mathrm{LD} 1]$} \\
\hline Policymakers & Director of Finance & Representations of the MoF (2) \\
\hline $\begin{array}{l}\text { Accounting } \\
\text { standards setter }\end{array}$ & KSAP members (2) & {$[\mathrm{KS} 1],[\mathrm{KS} 2]$} \\
\hline Experts & $\begin{array}{l}\text { Former team members for the formulation of the } \\
\text { public service agencies regulations (2) }\end{array}$ & {$[\mathrm{EX} 1],[\mathrm{EX} 2]$} \\
\hline
\end{tabular}

The interview transcripts were coded concerning the research questions. Two 'node' codes were assigned, namely 'Formulation of accounting standards' and 'Implementation of accrual accounting'. Based on an inductive-deductive coding 
approach (Miles and Huberman, 1994), the node codes were specified into a set of associated codes. The node codes came from the literature, whereas the associated codes emerged from the data (Young et al., 2016). Given the small number of interviews, the transcripts were hand-coded manually.

The interviews were conducted in Bahasa Indonesia and recorded with the prior permission of the interviewees. On average, the interviews lasted for 60 minutes. All English quotes in this manuscript have been translated by the author and checked by a proofreader. Additional validation checks on the interview results were done for mere factual data, such as accounting procedures, using other sources such as administrative reports. The coding scheme employed is summarized in Table 3.

Table 3.

The thematic coding scheme employed.

\begin{tabular}{|c|c|c|}
\hline Node codes & Associated codes & Indicators \\
\hline \multirow{2}{*}{$\begin{array}{l}\text { Formulation of } \\
\text { accounting } \\
\text { standards }\end{array}$} & $\begin{array}{l}\text { Background of the } \\
\text { standards }\end{array}$ & $\begin{array}{l}\text { The reason behind the new accounting } \\
\text { standards }\end{array}$ \\
\hline & Design of the standards & $\begin{array}{l}\text { Structure of the PSAP and financial } \\
\text { statements of the accounting entity and the } \\
\text { reporting entity }\end{array}$ \\
\hline \multirow{3}{*}{$\begin{array}{l}\text { Implementation } \\
\text { of accrual } \\
\text { accounting }\end{array}$} & $\begin{array}{l}\text { The dilemma of single } \\
\text { standards }\end{array}$ & Role of accounting as organizational control \\
\hline & Consolidation process & $\begin{array}{l}\text { Consolidation to the main ministry and state } \\
\text { treasury }\end{array}$ \\
\hline & Transition Period & The complexity in the transition period \\
\hline
\end{tabular}

\section{Results and Discussion}

\subsection{Formulation of Accounting Standards}

\subsubsection{Background of the Standards}

Following Law number 1/2004 on State Treasury, the government prepared regulations on the BLU and accounting standards at the same period. In 2005, the government enacted Government Regulation number 23/2005 on BLU financial management (hereafter: 'Regulation 23/2005').

KSAP issued PSAP numbers 1 to 12, enabling all government entities to prepare financial statements. Meanwhile, in that period, they had not identified any distinctive 
entities which have different characteristics in their financial management, such as BLU. KSAP decided that for the initial phase, it employed Cash-Towards-Accrual (CTA) basis in the transition period from 2005 to 2010. Meanwhile, the CTA-based SAP cannot fulfill the information needed by BLU since it does not cover the complexity of transactions.

Regulation 23/2005 states that as an 'accounting entity' managing the state budget, BLU must comply with the CTA-based SAP. However, as a 'reporting entity' with semibusiness characteristics, the information need is not sufficiently provided by the CTAbased financial statements. In order to fill this gap, BLU adopts the accrual-based SAK. In short, BLU applies these two accounting standards due to the differences in accounting basis.

The ideal accounting for a semi-business organization is accrual-based, in which rights and obligations are recognized when incurred rather than when the cash is disbursed. The accrual-based financial statements provide more comprehensive information. [KS1]

In a semi-business entity, the other reason is the need for performance measurements, particularly financial performance. The required information for measuring this performance is provided in the Income Statement or a similar report such as the Statement of Activities or Statement of Operational. Meanwhile, SAP provides only the Statement of Budget Realization (Laporan Realisasi Anggaran, LRA), which would not measure financial performance. Therefore, BLU prepares the accrual SAKbased financial statements.

Since 2015, the SAP and SAK have been applying the same accounting basis, i.e., accrual, resulting in no difference. In addition, the BLU has experienced problems in implementing these dual standards. Therefore, KSAP released PSAP 13 as the single accounting standard for BLU.

PSAP 13 is a vital accounting standard for BLU. The unification of the (dual) standards is expected to encourage financial statements for decision-making. For instance, the Cash Flow Statement can describe the more specific transaction, including operating, investing, and financing activities. [KS2] 


\subsubsection{Design of the Standards}

KSAP used the 'presentation of financial statements' approach for formulating accounting standards for BLU. This approach means that when there is no need for special standards, BLU should refer to general standards. The new accounting standards (PSAP 13) only arrange principles not covered in the PSAP 1 to 12 . In short, general principles are provided in those twelve PSAPs, while the PSAP 13 covers exceptions and distinctive principles only. The structure of the PSAP is provided in Table 4.

Table 4.

Structure of the PSAP

\begin{tabular}{|c|c|}
\hline Components & Usage \\
\hline Conceptual Framework & \multirow{14}{*}{$\begin{array}{l}\text { For all the government } \\
\text { entities, including BLU }\end{array}$} \\
\hline PSAP 01 Presentation of Financial Statements & \\
\hline PSAP 02 Statement of Budget Realization & \\
\hline PSAP 03 Statement of Cash Flow & \\
\hline PSAP 04 Notes to the Financial Statements & \\
\hline PSAP 05 Accounting for Inventory & \\
\hline PSAP 06 Accounting for Investment & \\
\hline PSAP 07 Accounting for Fixed Assets & \\
\hline PSAP 08 Accounting for Construction in Progress & \\
\hline PSAP 09 Accounting for Liabilities & \\
\hline PSAP 10 Correction of Errors, Change in Accounting & \\
\hline Policy and Extraordinary Events & \\
\hline PSAP 11 Consolidated Financial Statements & \\
\hline PSAP 12 Statement of Operational & \\
\hline $\begin{array}{l}\text { PSAP } 13 \text { Presentation of Financial Statements for } \\
\text { Public Service Agencies }\end{array}$ & Only for BLU \\
\hline
\end{tabular}

Source: author

The PSAP 13 is an exceptional standard, which is designated only for BLU, not for other government entities. This standard considers the BLU needs and covers the transaction complexity and different organization characteristics. As a reporting entity, BLU has a similar position to a local or central government in the accounting structure. Hence, these agencies must adopt different accounting standards.

Accounting for BLU is different compared to the other 'general' government agencies. In the government accounting structure, 'general' agencies are regarded as the accounting entity. Meanwhile, BLU is assigned as both an accounting entity and reporting entity. This dual role is a consequence of adopting a semi-autonomous model. 
The Indonesian Journal of Accounting Research - Sept, Vol. 24, No.3, 2021

As Table 5 details, reporting entity has to prepare complete financial statements, including the Statement of Cash Flow and Statement of Changes in Budget Balance (Saldo Anggaran Lebih, SAL).

Table 5.

Financial Statements for Accounting Entity and Reporting Entity

\begin{tabular}{llll}
\hline Accounting Entity & \multicolumn{2}{l}{ Reporting Entity } \\
\hline 1. & Statement of Budget Realization & 1. & Statement of Budget Realization \\
\hline 2. & Balance Sheet & 2. & Balance Sheet \\
\hline 3. & Statement of Operational & 3. & Statement of Operational \\
\hline 4. & Statement of Changes in Equity & 4. & Statement of Changes in Equity \\
\hline & 5. & Statement of Cash Flow \\
\hline & 6. & Statement of Changes in Budget Balance \\
\hline 5. & Notes to Financial Statements & 7. & Notes to Financial Statements
\end{tabular}

Source: author

The SAP, from 2005 to 2010, was CTA-based. Meanwhile, the BLU business characteristic needs an accrual-based standard. Therefore, BLU has to prepare financial statements based on the SAK (Regulation 23/2005). The accrual-based PSAPs of 2010 have been implemented since 2015. From 2015, with the PSAP 13 employs an accrual basis, BLU needs only to prepare a single financial statement.

In the process of preparing PSAP 13, the main constraint was on how to develop high accountability. This means how PSAP 13 enables financial statements to provide information and a tool of accountability and decision making. Therefore, the focus was on facilitating the financial statements as accountability reports and providing useful information for decision-making purposes. [KS1]

The challenge for us was on how to prepare accounting standard which is easily understood and implemented. Hence, we held a public hearing to ensure that users understand the standard. Managers of the BLU generally have similar qualifications, and they do not fully understand the concept of a semi-autonomous agency. The primary purpose of preparing financial statements is accountability rather than tools for decision-making. [KS2]

There are challenging topics in standard-setting-for instance, accounting standard for investment needs to consider complex regulations. Meanwhile, from a managerial view, the service provider has more complex topics in accounting due to services variability. 


\subsection{Implementation of Accrual Accounting}

\subsubsection{Dilemma of Single Standards}

The new accrual-based SAP has achieved the purpose of presenting accrual reporting. Therefore, ideally, BLU should prepare a single financial report. However, after enacting the PSAP 13, which employs an accrual basis, BLU does not need to follow the SAK. When the SAP replaces the SAK, this possibly terminates the existing SAK-based accounting system.

The design of the SAP-based software seems to assume that accounting officers have no adequate understanding of accounting. The system compiles data quarterly for preparing financial reports. Then, this system retrieves data at the end of the period. So, it can be argued that there is no ideal accounting process applied in this SAP-based software. The accounting officers can simply input transactions in order to generate financial reports. This means the financial statements are prepared only for compliance purposes. The report is compiled for a formal obligation purpose at the national level. [PM1]

Preferably, BLU should use accounting as a management tool for decision-making. In this sense, accounting should be a part of organization control. For instance, relevant authorities in the hospital which uses the voucher system make a payment request. They send the supporting documents such as contracts and invoices to the verification unit. Next, these documents are forwarded to the accounting division to be issued as a voucher.

Furthermore, the documents flow to the verification process. The voucher and other documents will be submitted to the authorized official (usually based on the nominal payment). Afterward, this will be returned to the accounting division as the source document. The accounting division signs this document and records the transaction. These processes are only found in the SAK-based accounting and are not designed in SAP-based accounting.

From the SAK perspective, accounting becomes a part of internal control. Once the auditors need to examine a transaction, they simply retrieve the reference number and request the supporting documents. The auditors are ensured that there is no unrecorded revenue by this control system. For example, they can prove that all the 
revenue collection processes have been passed when they do an a' test of transaction' for revenue.

A reliable system has recorded these revenues. The auditors assure that all the revenues have been collected since the cashier is 'located' at the bank. The verification function also assures them that all the collected revenues are recorded.

All the transactions have been recorded, and the documents flow the billing system ended in the journal. The voucher is forwarded to the accounting division, and there is no possibility of losing revenues since all of them are recorded.

These processes are not facilitated in SAP-based accounting. Meanwhile, the expected accounting model for BLU is accounting as a part of the internal control and becomes the input for decision-making purposes. SAK can simply provide billing information that could not be provided by SAP. [PM1]

The financial statements of BLU are not only for accountability purposes but also for assessing the implementation of budget flexibility. The SAK-based financial statements represent the achievement of the business plan (Rencana Bisnis dan Anggaran, RBA). In RBA, BLU structures the account and its components. The SAPbased financial statements cannot represent the achievement since the provided software bounds them.

Another perspective from the presented information is that the critical information previously presented by SAK could not be provided by SAP. For example, in most government agencies, revenue from renting their idle asset is classified as the 'nonservices revenue', a component of 'other income'. However, this will be inappropriate when the BLU, whose core business is renting assets, uses this account. [PM2]

According to [PM1] and [PM2], the SAK-based financial statements should be maintained due to some considerations. First, the government needs to provide a template of financial statements for BLU based on their tasks. For example, BLU, whose core task is asset rental, should use a different template from the one in the education service. Secondly, BLU needs flexible accounts. For instance, a change in strategic objectives requires an appropriate account change. This would be an obstacle when creating a new account goes through a long and formal process as in the SAP. 
Ideally, the BLU only needs to prepare single financial statements based on the new SAP. However, the SAP should be tested whether this accommodates the existing accounting system or not. When the accrual-based accounting process is eliminated, this will be a setback since real accounting is existing. [PM1]

Starting in 2015, both SAP and SAK are accrual-based. Consequently, they will generate similar reports. A possible difference might appear when SAP is implemented, while BLU still generates the SAK reports. They may simply use SAP to prepare the financial statements, consolidated to the central government financial statements (Laporan Keuangan Pemerintah Pusat, LKPP). However, this should not terminate the existing accounting system because it is essential for their businesses.

We remain to ask $B L U$ to submit the two financial statements for performance measurement purposes. The SAK-based financial statements can be labeled as 'managerial' or 'special purpose' statements instead of financial statements to avoid different interpretations. [PM2]

The information need and the output can be adjusted. The government simply needs to change the chart of accounts when these can be adjusted based on the categories of the BLU. The Directorate of Supervision on the BLU Financial Management in the MoF (hereafter: 'Directorate') administers, processes, and uses SAK-based financial statements. These financial statements are analyzed to measure financial performance.

We never use and analyze the old SAP-based financial statements because they are incomplete. Many performance assessment aspects come from the Statement of Operational, which is unavailable in the old SAP. Likewise, performance assessment at the management level uses data from the SAK financial statements. [PM1]

\subsubsection{Consolidation Process}

The Directorate conducts a review of synchronization between the SAP and SAK financial statements. The SAP financial statement, standardized based on the budget document. Several accounts are examined to ensure that the SAK-based reporting is following the SAP-based. There are corresponded accounts, such as depreciation, that should be equal between the two reports. 
As an accounting entity, BLUs' financial statements are consolidated to the main ministry. Meanwhile, as the reporting entity, these statements have to be consolidated to the state treasury. For the first consolidation step, the BLU consolidates the Cash Flow Statement and the Statement of Changes in SAL. Thus, these reports should be available at the main ministry level, although the transactions only come from the BLU.

For the second consolidation to the state treasury, BLU should observe the specific transaction to avoid double counting. For instance, as the reporting entity, funding from the state budget is recorded as 'operational revenue'. Meanwhile, as the accounting entity, this revenue has been consolidated to the main ministry. This transaction needs to be detected by the accounting system to avoid double recording.

Cash flows of the state treasury are different from the cash flows of the BLU (as a reporting entity). The differences may occur because, at the end of the accounting period, some revenues or expenses may not be recognized at the state treasury-the Balance Sheet presents 'cash', including those unrecognized. Thus, the Cash Flow Statement of the state should directly calculate BLUs' incoming cash, including those which are not recognized.

Consolidation has to validate whether all the transactions have been recorded because unrecognized transactions will not appear on the Cash Flow Statement in the state treasury. Transactions in the Cash Flow Statement include only those that are approved by the recognition mechanism. [KS2]

The BLUs recognize their revenue and expenditure to the state treasury. This recognition can be used to consolidate their cash flows to the treasury. This means that the recognition mechanism automatically consolidates both cash flows. The design of consolidation should enable this automatic process of cash-related transactions.

\subsubsection{Transition Period}

The preparation of SAP for BLU took a long time since specific transactions in this agency are significantly different from the other government institutions. KSAP did not only develop the standards but also prepared simulations to ensure the principles can be implemented. 
The effective date of PSAP 13 was by 2016. Meanwhile, at the beginning of 2016, the supporting regulations such as Buletin Teknis (in English: Technical Guidelines) and the accounting system were not completely prepared. According to [KS1], "as of July 2016, PSAP 13 has not been disseminated. Therefore, the 2016 period can be considered as a transition."

Regulation 23/2005 states that the Indonesian Institute of Accountants issues accounting standards for BLU. However, after the PSAP 13 was released, this regulation was not revised, which means that legally this is still a valid standard. Consequently, for the 2016 period, BLU had to prepare financial statements based on the two equally accrual-based standards, i.e., the SAK and SAP.

These standards generate similar reports. For instance, SAK generates the 'Statement of Activity' while SAP provides the 'Statement of Operational'. Formats of the financial statements will be different, although they hold the same accounting basis. [KS2]

Overall, based on the findings above, it became clear that agencies, policymakers, and experts consider dual accounting standards as unnecessary. BLU uses Government Accounting Standards, on the one hand, in order to be recognized as a government agency. On the other hand, they use Financial Accounting Standards to be acknowledged as 'professional' agencies. These complex rationales emerge from the language and meanings of accounting because accounting practices include specific vocabularies and discursive representation. These articulate rationales ways of knowing and managing organizations by viewing accounting in two ways: accounting as a legitimating device and accounting as a linguistic device (Potter, 2005, p.269, original emphasis). Table 6 summarizes the findings.

Table 6.

Summary of findings

Thematic codes Findings

Formulation of accounting standards Background of the Dual accounting standards. Standards accounting basis between SAP (CTA basis) and SAK (accrual basis). 


\section{Thematic codes Findings}

\begin{tabular}{|c|c|}
\hline & $\begin{array}{l}\text { The new accrual-based SAP. } \\
\text { In } 2010, \text { KSAP released the accrual-based SAP, i.e., PSAP } 1 \text { to } 12 \text {, } \\
\text { implemented from } 2015 .\end{array}$ \\
\hline & $\begin{array}{l}\text { The special PSAP for BLU. } \\
\text { In } 2015, \text { KSAP formulated PSAP } 13 \text { for BLU, which combines } \\
\text { accounting principles from the SAK and the accrual-based SAP. }\end{array}$ \\
\hline \multirow{3}{*}{$\begin{array}{l}\text { Design of the } \\
\text { Standards }\end{array}$} & Distinctive structure of the PSAP. \\
\hline & $\begin{array}{l}\text { While PSAP } 1 \text { to } 12 \text { are designed for all government entities, PSAP } 13 \text { is } \\
\text { only for BLU. The BLU should refer and adheres to PSAP } 1 \text { to } 12 \text { for } \\
\text { any general transactions. PSAP } 13 \text { only covers distinctive transactions in } \\
\text { BLU. }\end{array}$ \\
\hline & $\begin{array}{l}\text { Comparison of financial statements. } \\
\text { The financial statements of a reporting entity are different from an } \\
\text { accounting entity, which includes The Statement of Cash Flow and the } \\
\text { Statement of Changes in Budget Balance. }\end{array}$ \\
\hline \multicolumn{2}{|l|}{$\begin{array}{l}\text { Implementation of } \\
\text { accrual accounting }\end{array}$} \\
\hline \multirow[t]{2}{*}{$\begin{array}{l}\text { The dilemma of } \\
\text { Single Standards }\end{array}$} & $\begin{array}{l}\text { Control and decision-making. } \\
\text { In SAK, accounting is a part of organizational control and tools for } \\
\text { decision-making. Meanwhile, in the accrual-based SAP, accounting is an } \\
\text { accountability reporting. }\end{array}$ \\
\hline & $\begin{array}{l}\text { Performance measurement. } \\
\text { Information from the financial statements generated by the SAK-based } \\
\text { accounting system is needed for performance measurement purposes. } \\
\text { The accrual-based SAP does not provide this information. }\end{array}$ \\
\hline \multirow{3}{*}{$\begin{array}{l}\text { Design of } \\
\text { Consolidation }\end{array}$} & First: to the main ministry. \\
\hline & $\begin{array}{l}\text { BLU consolidates the Cash Flow Statement and Statement of Changes in } \\
\text { SAL to the main ministry. Thus, these reports should be available at the } \\
\text { main ministry level. }\end{array}$ \\
\hline & $\begin{array}{l}\text { Second: to the state treasury. } \\
\text { BLU should observe the specific transaction to avoid double counting in } \\
\text { the state treasury. }\end{array}$ \\
\hline Transition Period & $\begin{array}{l}\text { Complexity in the transition period. } \\
2016 \text { was a transition period in which BLU prepared two sets of financial } \\
\text { statements based on two equally accrual-based accounting standards. }\end{array}$ \\
\hline
\end{tabular}

\section{Concluding Remarks}

\subsection{Conclusion}

Accrual accounting has been adopted in Indonesia since 2005 for semiautonomous agencies as a consequence of agencification. The government considers agencification as an incremental change process that attempts to improve the quality of financial reports. The adoption of accrual accounting has become a cornerstone of 
agencification reforms. Financial information is used as a form of results control, where parent departments monitor and evaluate the achievements of the agency objectives (Öberg and Wockelberg, 2021, p.5).

The study aims to investigate this phenomenon deeply rather than at a surface level (Tucker, 2021, p.237). From the interviews, agency managers share close perceptions about the practice of accounting, including the introduction of accrual accounting and the use of dual standards. The introduction of accrual accounting is expected as a challenge to drive accounting reform. In the meantime, the managers consider the use of dual standards at the beginning of the adoption as unnecessary.

This research shows that the central issue of accounting in BLU is that formulation of the new accounting standards for BLU is encouraged by problems in implementing dual accounting standards. Accrual-based standards have stimulated fundamental change in accounting at the agencies. The main function of SAP-based financial statements is for consolidation purposes. Reports generated from the existing SAKbased accounting system are still required to support semi-business activities within the frame of entrepreneurship-driven public management reforms (Haque, 2020). Therefore, this can be labeled as a 'managerial report'. This report can be considered an effort to link the agencies' performance at a local level to 'national accountability' (Hammond et al., 2019, p.1157).

The accounting principles have been gradually implemented at the agencies as a part of organizational control. However, the existing SAK-based accounting system may be terminated since the enactment of the PSAP 13. Based on the interviews, BLU found various constraints in designing the accounting system. This could hinder them improve the quality of financial reporting. These findings support Shidarta and Van Huis' (2020) conclusion that agencification has increased state revenues significantly, yet accountability has not improved accordingly.

\subsection{Implication and Limitation}

This study reveals three lessons learned to implement accrual-based accounting for semi-autonomous agencies. First, the accounting system developer has to understand the accounting standards and the agency characteristics. This is important since semi- 
autonomous agencies are different from other government agencies. Accrual accounting has been adopted in semi-autonomous agencies to generate 'more complete' figures in financial statements such as account receivables and accrued expenses. Second, the accounting system should be tested. A piloting period is needed instead of direct implementation. The preparation of financial statements is linked with notions of 'accountability, 'transparency', 'responsibility', and 'efficiency' (Potter, 1999). Third, the standard-setter should disseminate the accrual-based accounting to all stakeholders, especially the government accounting system developers and the agencies, including local agencies. A BLU is allowed to develop its accounting systems for managerial purposes. After being granted BLU status, they have two years to develop and implement accrual-based accounting systems, which include financial, fixed asset, and cost accounting systems.

There are some significant limitations to this research. One is the small number of cases from one particular country, which implies that the results of this study can by no means be generalized. Dual accounting standards may be needed, with expanded cases to capture that practice. Thus, extending the research across various sectors and countries would be a significant future study challenge. However, emerging issues have been revealed, which provide a potential basis for further research. Another weakness of the study results from the agency-specific characteristics involved, i.e., size, task, and main ministry, which do not represent all agency variations. The relevance of including another characteristic, such as the source of income and organizational structure, should not be dismissed. Notwithstanding these issues, this study could be considered an attempt to provide a step towards a better understanding of the accounting side of agencification by showing the dynamics of the accounting standards and reporting practice in a developing country setting.

\section{Acknowledgments}

Interview contributions from the KSAP members, BLU officials, and experts are gratefully acknowledged. An earlier version of this study was presented at the $6^{\text {th }}$ International Conference on Educational Management Administration and Leadership, 
Universitas Pendidikan Indonesia, and the $15^{\text {th }}$ Education Doctoral Research Conference, University of Birmingham. The author wishes to thank Windraty Ariane Siallagan (the Ministry of Finance) and the anonymous reviewers for their priceless advice. Research assistance was ably and enthusiastically provided by Amriza Nitra Wardhani, Fandy Anggara Putra, and Octarina Ardyanti.

\section{References}

Aliu, F. and Ibikunle, B. (2020). Agencification and service delivery: perspective of traffic management in Lagos State Nigeria. Journal of Contemporary Issues in Management and Communication Studies, 1(1), 165-180.

Bach, T. (2012). Germany. Verhoest, K., Van Thiel, S., Bouckaert, G. and Lægreid, P. In Government Agencies: Practices and Lessons from 30 Countries. New York: Palgrave Macmillan, 166-178.

Boeije, H. (2010). Analysis in Qualitative Research. London: Sage Publications.

Boston, J., Martin, J., Pallot, J., and Walsh, P. (1996). Public Management: The New Zealand Model. Auckland: Oxford University Press.

Bouckaert, G., \& Verhoest, K. (1999). A Comparative Perspective on Decentralisation As a Context for Contracting in the Public Sector: Practice and Theory, in Y. Fortin(Eds.), La Contractualisation dans le Secteur Public des Pays Industrialisés depuis 1980. Paris: Harmattan.

Christensen, T., Lie, A., and Laegreid, P. (2008). Beyond New Public Management: agencification and regulatory reform in Norway. Financial Accountability \& Management, 24(1), 15-30.

Cingolani, L. and Fazekas, M. (2020). The role of agencification in achieving value-for-money in public spending. Governance, 33, 545-563.

Douma, S., \& Schreuder, H. (1998). Economic Approaches to Organizations, 2nd edition. London and New York: Prentice-Hall.

Dunleavy, P. (1991). Democracy, Bureaucracy and Public Choice: Economic Explanations in Political Science. London: Harvester Wheatsheaf.

Egeberg, M., \& Trondal, J. (2009). Political leadership and bureaucratic autonomy: effects of agencification. Governance, 22(4), 673-688.

Flinders, M. (2004). Distributed public governance in the European Union. Journal of European Public Policy, 82(4), 883-909. 
Flinders, M., \& Smith, M. (1999). Realizing the democratic potential of quangos, in Flinders, M., \& Smith, M. (Ed.), Quangos, Accountability, and Reform: The Politics of QuasiGovernment. London: Palgrave Macmillan, 201-210.

Gains, F. (1999). Understanding Department - Next Steps Agency Relationships, (Ph.D. Thesis, University of Sheffield).

George, A. L., \& Bannet, A. (2005). Case Studies and Theory Development in the Social Sciences. London: MIT Press.

Given, L. M. (2008). The Sage encyclopedia of qualitative research methods. Los Angeles: Sage Publications.

Greve, C., Flinders, M., and Van Thiel, S. (1999). Quangos — what's in a name? Defining quangos from a comparative perspective. Governance, 12(2), 129-146.

Hammond, J., Speed, E., Allen, P., McDermott, I., Coleman, A., and Checkland, K. (2019). Autonomy, accountability, and ambiguity in arm's-length meta-governance: the case of NHS England. Public Management Review, 21(8), 1148-1169.

Haque, M. S. (2020). Entrepreneurship-driven public management reforms in Southeast Asia: Critical implications for public accountability. Public Administration and Development, 40, 220-231.

Harun, H., Peursem, K. V., and Eggleton, I. (2012). Institutionalization of accrual accounting in the Indonesian public sector. Journal of Accounting \& Organizational Change, 8(3), $257-285$.

Hood, C., \& Jackson, M. (1991). Administrative Argument. Dartmouth: Aldershot.

Howell, E. (2019). EU agencification and the rise of ESMA: are its governance arrangements fit for purpose? Cambridge Law Journal, 78(2), 324-354.

Ika, S. R., \& Widagdo, A. K. (2013). Transitioning from cash basis to the full accrual basis of Indonesian public sector: Obstacles and recent progresses. Jurnal Bisnis dan Ekonomi EFEKTIF, 4(1), 48-61.

James, O. (2000). The 'Next Steps' agency model in UK central government 1988-1998 with special reference to the Benefits Agency (Ph.D. thesis, London School of Economics and Political Science).

James, O. (2003). The Executive Agency Revolution in Whitehall: Public Interest Versus Bureaushaping Perspectives. Basingstoke: Palgrave Macmillan.

James, O., Petrovsky, N. Moseley, A., and Boyne, G. A. (2015). The politics of agency death: ministers and the survival of government agencies in a parliamentary system. British Journal of Political Science), 1-22. 
Kasim, E. Y. (2015). Restatement and accrual basis issue in government accounting in Indonesia, the first International Conference on Economics and Banking, Atlantis Press.

Kosar, K. R. (2011). The Quasi Government: Hybrid Organisations with Both Government and Private Sector Legal Characteristics, Congressional Research Service, Report for Congress. Retrieved from: https://www.fas.org/sgp/crs/misc/RL30533.pdf

Lampropoulou, M. and Oikonomou, G. (2020). The "Trilemma" of public bodies: bureaucratic structures versus agencies under policy conditionality, Administration \& Society, 52(9), 1299-1332.

Maggetti, M., Di Mascio, F. and Natalini, A. (2020). National regulators, regulatory networks, and European agencies: Connecting the dots. Public Policy and Administration, 36(3), $275-280$.

Migliorati, M. (2020). The post-agencification stage between reforms and crises. A comparative assessment of EU agencies' budgetary development. Journal of Common Market Studies, 58(6), 1393-1412.

Migué, J. L., Bélangér, G., and Niskanen, W. (1974). Toward a general theory of managerial discretion. Public Choice, 17(1), 27-47.

Miles, M. B., \& Huberman, A. M. (1994). Qualitative Data Analysis: An Expanded Sourcebook. Thousand Oaks: Sage Publications.

Nasi, G., \& Steccolini, I. (2008). Implementation of accounting reforms. Public Management Review, 10(2), 175-196.

Niskanen, W.A. (1971). Bureaucracy and Representative Government. Chicago: AldineAtherton.

Öberg, S. and Wockelberg, H. (2021). Agency control or autonomy? Government steering of Swedish government agencies 2003-2017. International Public Management Journal, 24(3), 1-20.

OECD. (2002). Distributed Public Governance: Agencies, Authorities, and Other Autonomous Bodies. Paris: OECD.

Osborne, D., \& Gaebler, T. (1992). Reinventing Government: How the Entrepreneurial Spirit is Transforming the Public Sector. New York: Plum Book.

Overman, S., \& van Thiel, S. (2016). Agencification and public sector performance: A systematic comparison in 20 countries. Public Management Review, 18(4), 611-635.

Pierre, J. (2004). Central agencies in Sweden: a report from Utopia, in Pollit, C., \& Talbot, C. (Eds.), Unbundled Government: A Critical Analysis of the Global Trend to Agencies, Quangos, and Contractualisation. New York: Routledge, 319-341.

Pliatzky, L. (1992). Quangos and agencies. Public Administration, 70(4), 555-563. 
Pollit, C. (2016). Advanced Introduction to Public Management and Administration. Cheltenham: Edward Elgar Publishing.

Pollit, C., Bathgate, K., Caulfield, J., Smullen, A., and Talbot, C. (2001). Agency fever? Analysis of an international policy fashion. Journal of Comparative Policy Analysis: Research and Practice, 3(3), 271-290.

Pollitt, C. (2004). Theoretical overview, in Pollitt, C. and Talbot, C. (Eds.), Unbundled Government: A Critical Analysis of the Global Trend to Agencies, Quangos, and Contractualisation. New York: Routledge, 319-341.

Pollitt, C., \& Talbot, C. (2004). Unbundled Government: A Critical Analysis of the Global Trend to Agencies, Quangos, and Contractualisation. London: Routledge.

Pollitt, C., Talbot, C., Caulfield, J., and Smullen, A. (2004). Agencies: How Governments do things through Semi-Autonomous Organizations. Houndmills: Palgrave Macmillan.

Potter, B. (1999). The power of words: Explaining recent accounting reforms in the Australian public sector. Accounting History, 4(2), 43-72.

Potter, B. (2005). Accounting as a social and institutional practice: Perspectives to enrich our understanding of accounting change, Abacus, 41(3), 265-289.

Restianto, Y. E. and Bawono, I. R. (2020), Pengelolaan Keuangan BLU/BLUD Berbasis Teknologi Informasi. Second Edition. Yogyakarta: UPP STIM YKPN.

Ribbens, J. (1989). Interviewing: An 'unnatural situation'? Women's Studies International Forum, 12,(6), 579-592.

Sahlin-Anderson, K. (1996). Imitating by editing success: the construction of organizational fields, in Czarniawksa, B. and Sevon, G (Eds) Translating Organizational Change. Berlin: De Guyter, 69-91.

Schick, A. (2002). Why most developing countries should not try New Zealand reforms. The World Bank Research Observer, 13(1), 123-31.

Shidarta and Van Huis, S. (2020). Between revenues and public service delivery: SOEs and PSAs in Indonesia. Bijdragen Tot De Taal-, Land- En Volkenkunde, 176(2/3), 304-337.

Siallagan, W. \& Stewart, J. (2014). Implementing financial management reform in Indonesia: The significance of within-country variability. Asian Review of Public Administration, 25(2), 64-77.

Smullen, A. (2004). Lost in translation? Shifting interpretations of the concept of agency: the Dutch case, in Pollit, C., \& Talbot, C. (Eds.), Unbundled Government: A Critical Analysis of the Global Trend to Agencies, Quangos, and Contractualisation. London: Routledge. 
Szesciło, D. (2020). Agencification revisited: trends in consolidation of central government administration in Europe. International Review of Administrative Sciences, Forthcoming, https://doi.org/10.1177/0020852320976791.

Talbot, C. (2004). The Agency Idea. Sometimes Old, Sometimes New, Sometimes Borrowed, Sometimes Untrue, in Pollit, C., \& Talbot, C. (Eds.), Unbundled Government: A Critical Analysis of the Global Trend to Agencies, Quangos, and Contractualisation. New York: Routledge.

Taliercio, R. (2004). The design, performance, and sustainability of semi-autonomous revenue authorities in Africa and Latin America, in Pollit, C., \& Talbot, C. (Eds.), Unbundled Government: A Critical Analysis of the Global Trend to Agencies, Quangos, and Contractualisation. New York: Routledge.

Thynne, I. (2003). Making sense of organizations in public management: A back-to-basics approach. Public Organization Review, 332, 317-332.

Trondal, J. (2014). Agencification. Public Administration Review, 74(4), 545-549.

Tucker, B. P. (2021). Methodological Insights Jumping through hoops: publishing interviewbased management accounting research. Accounting, Auditing \& Accountability Journal, 34(1), 223-241.

Ugyel, L., Sause, L. and Gorea, E. (2020). Dynamics and tensions of implementing agencification reforms: Experiences of District Development Authorities in Papua New Guinea. Australian Journal of Public Administration, 1, 1-14.

Van Thiel, S. (2001). Quangos: Trends, Causes, and Consequences. Aldershot: Ashgate.

Van Thiel, S. (2004a). Quangos in Dutch Government, in Pollit, C., \& Talbot, C. (Eds.), Unbundled Government: A Critical Analysis of the Global Trend to Agencies, Quangos, and Contractualisation. New York: Routledge, 167-183.

Van Thiel, S. (2004b). Trends in the public sector: Why politicians prefer quasi-autonomous organizations. Journal of Theoretical Politics, 16(2), 175-201.

Verhoest, K., Roness, P., Verschuere, B., Rubecksen, K., and MacCarthaigh, M. (2010). Autonomy and Control of State Agencies: Comparing States and Agencies. Basingstoke: Palgrave Macmillan.

Verhoest, K., Van Thiel, S., Bouckaert, G., and Lægreid, P. (2012). Government Agencies: Practices and Lessons from 30 Countries. New York: Palgrave Macmillan.

Waluyo, B. (2018). Balancing financial autonomy and control in agencification: Issues emerging from the Indonesian higher education. International Journal of Public Sector Management, 31(7), 794-810. 
The Indonesian Journal of Accounting Research - Sept, Vol. 24, No.3, 2021

Yamamoto, K. (2004). 'Agencification in Japan: Renaming or revolution?', in Pollit, C., \& Talbot, C. (Eds.), Unbundled Government: A Critical Analysis of the Global Trend to Agencies, Quangos, and Contractualisation. New York: Routledge.

Yee, W-H. and Van Thiel, S. (2020). Global reform meets local context: cultural compatibility and practice adoption in public sector reform. International Journal of Public Sector Management, 34(2), 224-240.

Yesilkagit, K. (2004). Bureaucratic autonomy, organizational culture, and habituation. Administration and Society, 36(5), 528-552.

Yesilkagit, K., \& van Thiel, S. (2008). Political influence and bureaucratic autonomy. Public Organization Review, 8(2), 137-153.

Yin, R. E. (2003). Case Study Research: Design and Methods. London: Sage Publications.

Young, S., Nagpal, S. and Adams, C. A. (2016). Sustainable procurement in Australian and UK universities. Public Management Review, 